\title{
Core competencies of women entrepreneur in building superior online business performance in Indonesia
}

\author{
John Sihotanga, R.A. Aryanti Wardaya Puspokusumo ${ }^{a^{*}}$, Yen Sun ${ }^{a}$ and Dadang Munandara
}

${ }^{a}$ Partnership research by International Women University (IWU) and Bina Nusantara University (BINUS), Indonesia

\begin{tabular}{l}
\hline C H R O N I C L E \\
\hline Article history: \\
Received: November 3, 2019 \\
Received in revised format: No- \\
vember 282019 \\
Accepted: December 3, 2019 \\
Available online: \\
December 4, 2019 \\
\hline Keywords: \\
Core competencies \\
Partnership Development Capa- \\
bility \\
Digital Marketing Capability \\
Online Business Performance \\
Women Entrepreneur
\end{tabular}
A B S T R A C T

Most of online entrepreneurs in Indonesia are women, but their capabilities as professional online entrepreneurs are still less superior. This study aimed to investigate the core competencies of online women entrepreneur and verify the effects on their business performance. The study uses two stages of research: explanatory and confirmatory research. The result of explanatory research, has identified two capabilities as a core competency in building superior online business, i.e. partnership development and digital marketing capability. Yet, by confirmatory research, the study has found that both strategies had significant effects on building a superior business. This model can be also adopted by other online entrepreneurs to build their success in online business.

\section{Introduction}

(C) 2020 by the authors; licensee Growing Science, Canada

During the last five years, the retail e-commerce or online business in Indonesia has grown rapidly with the growth of 20$30 \%$ annually (Indonesia-Investment, 2018). However, when compared with other countries such as China and United States, the Indonesia's e-commerce transactions is still lagging behind (Maguire, 2014; Barney, 2001). The transactions value of ecommerce retail in 2013 is still around 4 billion US dollars (60 trillion rupiah) or $0.1-0.2 \%$ of the national retail revenue, but in 2016 it increased rapidly to 25 billion US dollars ( \pm 350 trillion rupiah) or 4-5\% of total national retail income. According to Sihotang (2016), the development of e-commerce in Indonesia will be faster than before primarily due to four main factors, i.e.: 1) the acceleration of internet network construction 2) the price of mobile is getting cheaper 3) lifestyle changes related to the change of generation 4) economic growth of above $5 \%$. To identify the phenomenon of online business performance in Indonesia, researchers have conducted a pre-survey by desk research method on March-August 2018. Researchers observed a sample of 500 online sellers in the five biggest retail ecommerce providers in Indonesia (100 online sellers each from Tokopedia, Bukalapak, Sophee, Blibi and Blanja). Based on the pre-research, it showed that mostly were women entrepreneur $(55 \%)$. Further pre-research has shown that the sustainability of business performance of woman entrepreneur, could be seen as Fig. 1. There were only around $8 \%$ of the women entrepreneurs who have a superior business performance, where their sales increasing continuously. Around 12\% increased slightly, 35\% fluctuated, and $45 \%$ underperformed. In order to find out the key success factors for women entrepreneurs to run their online business, some interviews were conducted via phone to 
50 woman entrepreneur. Based on that interviewed, ten competencies were identified as the main factors that contributes to their success or failure, i.e.

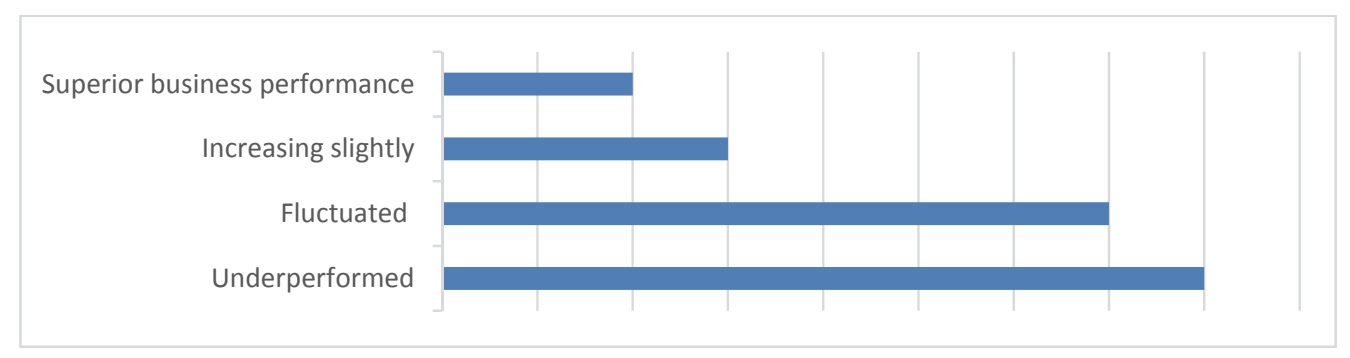

Fig. 1. Online Business Performance of Women Entrepreneur in Indonesia

Table 1

Key Success Factor of Online Woman Entrepreneur

\begin{tabular}{llcl}
\hline No & \multicolumn{1}{c}{ Capability according to respondents } & Number of respondents who filled out & Based on Theory \\
\hline 1 & Building relationship with supplier & 18 & Partnership Development Capability \\
2 & Social media marketing capability & 17 & Digital Marketing Capability \\
3 & Contracting \& negotiation capability & 15 & Partnership Development Capability \\
4 & Selecting the right partner & 12 & Partnership Development Capability \\
5 & Managing trust with partner & 12 & Partnership Development Capability \\
6 & Managing relationship with customer & 11 & Digital Marketing Capability \\
7 & Build customer quality of services & 10 & Digital Marketing Capability \\
8 & Manage low price strategy & 9 & Digital Marketing Capability \\
9 & Digital marketing capability & 9 & Digital Marketing Capability \\
10 & Online promotion capability & 8 & Digital Marketing Capability \\
\hline Source : Pre-survey & &
\end{tabular}

Source : Pre-survey

Based on theory and previous studies, all those competencies can be grouped into two core competencies, namely partnership development capability and digital marketing capability. More than $50 \%$ of online business owners carry out the production process. The complexity of their production varies considerably, some start from product design, procurement of raw materials, processing to finished goods, storing, distributing and selling in brick and mortar models by combining offline and online. Meanwhile, there are also some entrepreneurs who assemble semi-finished products according to consumer's needs and sell them through offline and online systems. These business models are quite complex and have a high risk (Batemen et al., 2007). Most of online business are SME entrepreneurs, where generally known as having various limitations, such as limitations in finance, knowledge, technology, people, etc. Based on the strategic management theory, companies that have inferior resources, may be able to obtain superior business performance if they are able to collaborate with other parties whom having a distinct competency. This mean that woman online entrepreneur, need to build strategic partnerships with various parties. Traditional marketing is no longer qualified (Ryan, 2016; Boose, 2010; Triantono \& Puspokusumo, 2018; Wheelen \& Hunger, 2012). Digital marketing capabilities become one of the important competencies in this era, especially in e-commerce business (Chaffey \& Ellis-Chadwick, 2019). Based on the preceding description, this study aims to investigate the roles of both of partnership development capability and digital marketing capability in building successful online business performance of women entrepreneur in Indonesia.

\section{Literature review}

\subsection{Core competence}

Core competencies is the basis of company competitiveness. It was initially introduced by Prahalad and Hamel (1990) as "a good combination of various resources and skills and can distinguish companies in the market”. Based on the pre-survey, there were two competencies played an important role in supporting women entrepreneurs in Indonesia, i.e. partnership development and digital marketing capability.

\subsection{Partnership development capability}

Partnership has been the main concept for the development of cooperation since the middle of 2018. When development theories have evolved, they also have a commitment about support, cooperation, partnerships, and solidarity. According to Isoraite (2009), strategic partnerships can be built through four stages: formulating goals and strategies, selecting appropriate partners, negotiating and formulating good contracts and carrying out cooperation and managing good relationships. The partnership development strategy includes business case preparation activities. Proper partner selection needs to be done by analyzing the strengths and weaknesses of each partner. Before entering into a contract, it is necessary to negotiate which 
regards to each rights and responsibilities. Making contracts that are unclear will be risky and may potentially cause problems later in the day. If the contract has been prepared, the next step is to carry out cooperation by building intense communication. Many collaborations fail to do so because of the lack of communication and mutually dominant behavior.

\subsection{Digital marketing capability}

Digital marketing is one of the recent most advanced fields when it comes to big data (Opreana \& Vinerean, 2015). According to Opreana and Vinerean (2015), to build a successful digital marketing, the online marketers need to have at least four capabilities, i.e. 1) developing attractive and relevant content marketing according to the needs of the audience. First, marketer should understand who is the target of content marketing, and try to identify their need and requirement 2) the ability to utilize the Search Engine Optimization (SEO). SEO is an online marketing tool that makes it easy for prospects to find organization content. 3) using marketing social media. Online social networking is very effective in disseminating information to offer product directly to the right customer 4) building marketing communications to get and convince consumers about the products and services sold.

\section{4. online business performance}

Online business performance illustrates the success of online businesses that provide value to entrepreneur and customers. Some previous researchers who have described measurements of online business performance, such as Hayes (2005), Bremser and Chung (2005), Zhang and Okoroafo (2014). Almost all of these researchers always use four dimensions to measure the online business performance:1) the dimensions of financial performance as measured by indicators of achievement of revenue and profit targets. 2) dimensions of customer performance, which are measured by indicators of achieving the target number of new customers and the number of loyal customers. 3) process performance dimensions measured through indicators of satisfaction with the delivery process and the conformity of goods ordered. 3) the dimensions of web traffic performance as measured by indicators of ease of access and traffic growth.

\section{The research model}

According to BPS data (2013), more than 98\% companies in Indonesia are micro, small and middle enterprises that having a lot of barriers. Based on 3C's Model theory by Sri and Sucherly (2012), a company that has some inferior resources may get a superior performance by developing a strategic relationship with various partners such as supplier, competitor, customer, etc. (Ireland et al., 2013). The current traditional marketing is no longer capable of attracting consumer, the life style of most people in Indonesia has been changing to digital mindset. Indonesia's population is recorded as the youngest population in the world (World Bank Report, 2013), where more than 50\% of the population in Indonesia are young and digital generation with great potential to be the consumer of shopping online. Based on the explanation above, the research model could be described as in this Fig. 2 as follows,

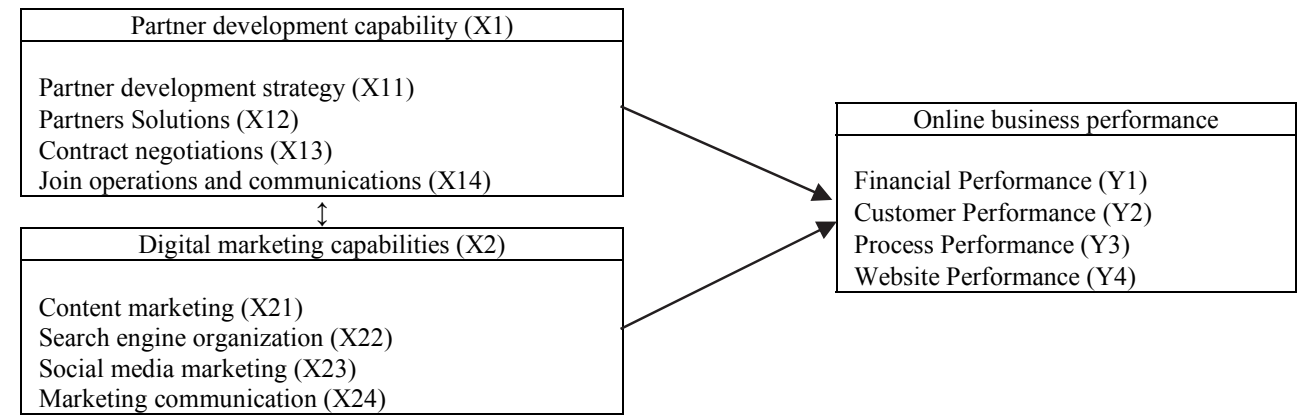

Fig. 2. Research model

Hypothesis:

1) Ho (1): Partnership development capability (X1) has no a significant effect on Online business performance (Y).

2) Ho (2): Digital marketing capability (X2) has no a significant effect on Online business performance (Y).

3) Ho (3): Both Partnership development capability (X1) and Digital marketing capability (X2) have no a significant effect on Online business performance $(\mathrm{Y})$.

\subsection{Methods}

This research uses two stages of research methods, the first is a qualitative method and the second is the quantitative method. Qualitative methods have been used in pre-research that has found two core competencies of women entrepreneurs to run online businesses in Indonesia, namely partnership development capability and digital marketing capability. Furthermore, to determine the influence of the two competencies above both partially and simultaneously on the achievement of superior 
online performance, a quantitative verification method uses questionnaire survey method. The sample of this research is the women entrepreneur who operate online store which registered in one or more well-known retail e-commerce marketplace providers in Indonesia, such as Shopee, Tokopedia, Blibli, Blanja and Bukalapak. The survey was conducted from October to November 2018. The questionnaire survey was send to 300 online store owner/managers which is selected based on the sampling frame. At the end of the survey, there were only 124 women entrepreneurs who returned the questionnaires giving a response rate of 41.3 percent.

\section{Results}

Techniques of data analysis for hypothesis testing used in this study is SmartPLS 3.2.8 Professional Version, to be able to process data more than 100 observations. In accordance with PLS-SEM algorithm, the first step is to test the validity and reliability. An assessment of reliability and validity in SEM, are expressed by Convergent Validity, Composite Reliability, Average Variance Extracted (AVE) and Cronbach Alpha. The value of Convergent validity or outer loading factors, which expected is $>0.7$ and $<0.4$ should be deleted (Hair et al., 2013). As shown in Fig. 3 below, we have found that all 24 indicators are valid (range between 0.822 to 0.911 ). Based on quality criteria shown in Table 2, the composite reliability (CR) of each construct ranged from 0.818 and 0.933 which was considered satisfactory and the Average Variance Extracted (AVE) of each construct ranged from 0.546 and 0.826 which is also quite above the threshold of 0.5 . Likewise, Cronbach Alpha (CA) ranges from 0.730 and 0.908 which are also considered satisfactory. This means that the internal consistency of validity and reliability has been achieved.

Table 2

Construct Reliability \& Validity

\begin{tabular}{|c|c|c|c|c|}
\hline No & Con-struct & $\mathrm{CR}$ & AVE & $\mathrm{CA}$ \\
\hline 1 & $\mathrm{X} 1$ & 0.925 & 0.607 & 0.908 \\
\hline 2 & $\mathrm{X} 11$ & 0.847 & 0.735 & 0.741 \\
\hline 3 & $\mathrm{X} 12$ & 0.860 & 0.755 & 0.780 \\
\hline 4 & $\mathrm{X} 13$ & 0.901 & 0.820 & 0.743 \\
\hline 5 & X14 & 0.886 & 0.795 & 0.918 \\
\hline 6 & $\mathrm{X} 2$ & 0.933 & 0.636 & 0.763 \\
\hline 7 & $\mathrm{X} 21$ & 0.894 & 0.808 & 0.761 \\
\hline 8 & $\mathrm{X} 22$ & 0.893 & 0.807 & 0.730 \\
\hline 9 & $\mathrm{X} 23$ & 0.881 & 0.787 & 0.790 \\
\hline 10 & X24 & 0.905 & 0.826 & 0.881 \\
\hline 11 & $\mathrm{Y}$ & 0.903 & 0.546 & 0.889 \\
\hline 12 & Y1 & 0.855 & 0.747 & 0.739 \\
\hline 13 & Y2 & 0.843 & 0.729 & 0.774 \\
\hline 14 & Y3 & 0.847 & 0.739 & 0.757 \\
\hline 15 & Y4 & 0.818 & 0.692 & 0.856 \\
\hline
\end{tabular}

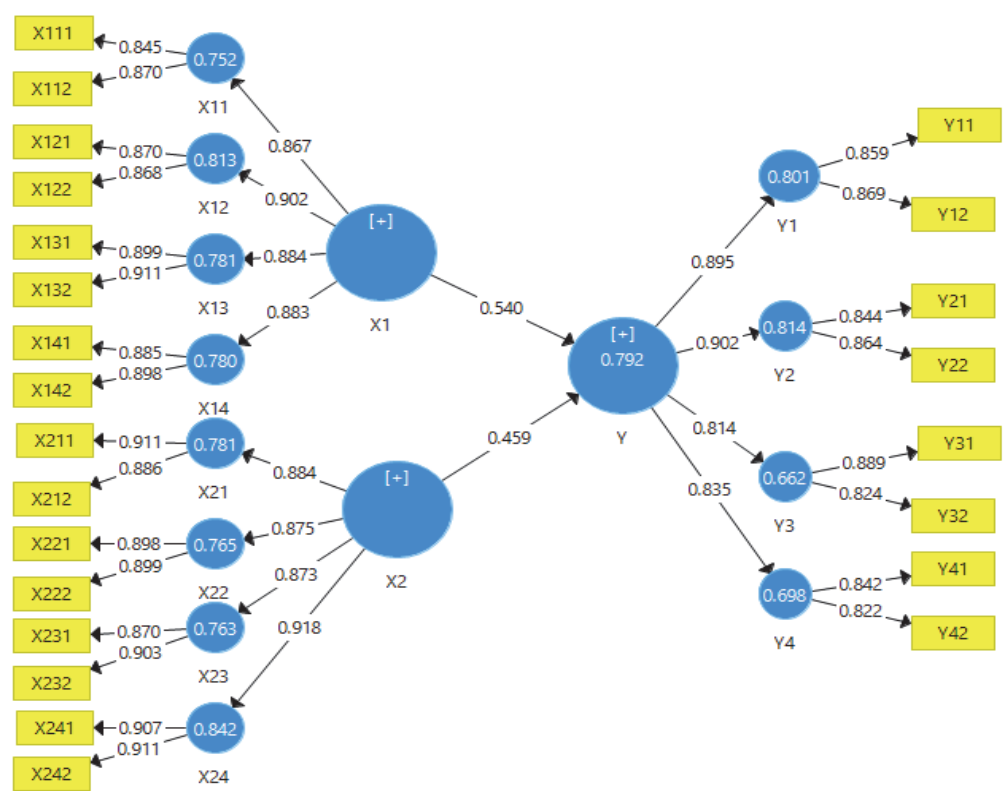

Fig. 2. The results of path analysis

When it has been confirmed that the measurement of construct was identified valid and reliable, the next action is to assess the result of structural model measurement. There are five procedures to assess structural model (Hair et al., 2014): 1) Assessing collinearity issue. When two or more independent variables are highly inter-correlated, may have potentially in multicollinearity issue. Multicollinearity may exist when the coefficient of VIF (Variance Inflation Factor) $\geq 4.0 .2$ ) Assessing 
the path coefficient significance: The path coefficient may significant, when the T-statistics values $>1.98$. 3) Assess the level of R-square (R2): R-square indicates the amount of variance explained by the exogenous variable in its endogenous counterpart (Hair et al., 2014). 4) Assess the effect size f2 to evaluate whether exogenous constructs have a substantive impact on endogenous constructs. 5) Assess the predictive relevance (Q2): Q2 assessment not only built around the values of the model but also the parameter estimates of the model. As such, output summary of data processing by SmartPLS related (Ghazali, 2014; Hair et al., 2014) to the structural model assessment can be seen in Table 3.

Table 3

The results of Inner model measurement

\begin{tabular}{|c|c|c|c|c|c|c|c|}
\hline No & Causality Rela- & VIF & Path & $\mathrm{R}^{2}$ & $\mathrm{f}^{2}$ & T Stat. & Remark \\
\hline 1 & $\mathrm{X} 1 \rightarrow \mathrm{Y}$ & 1.522 & 0.540 & N/A & 0.919 & 11.993 & \multirow{3}{*}{$\begin{array}{l}\text { 1) There isn't any collinearity issues among constructs, } \\
\text { as VIF }<4.0 \text { and }>0.25\end{array}$} \\
\hline 2 & $\mathrm{X} 11 \rightarrow \mathrm{X} 1$ & 1.000 & 0.867 & 0.752 & 3.027 & 39.626 & \\
\hline 3 & $\mathrm{X} 12 \rightarrow \mathrm{X} 1$ & 1.000 & 0.902 & 0.813 & 4.361 & 56.783 & \\
\hline 4 & $\mathrm{X} 13 \rightarrow \mathrm{X} 1$ & 1.000 & 0.884 & 0.781 & 3.576 & 54.218 & \multirow{3}{*}{ The model has predictive relevance, as $\mathrm{Q}^{2}>0$} \\
\hline 5 & $\mathrm{X} 14 \rightarrow \mathrm{X} 1$ & 1.000 & 0.883 & 0.780 & 3.553 & 46.250 & \\
\hline 6 & $\mathrm{X} 2 \rightarrow \mathrm{Y}$ & 1.522 & 0.459 & N/A & 0.666 & 8.251 & \\
\hline 7 & $\mathrm{X} 21 \rightarrow \mathrm{X} 2$ & 1.000 & 0.884 & 0.781 & 3.576 & 46.506 & \multirow{3}{*}{$\begin{array}{l}\mathrm{X} 1 \text { has significance effect on } \mathrm{Y} \text {, as Tstat.(11.993) > } \\
1.98 \rightarrow \text { Ho is rejected }\end{array}$} \\
\hline 8 & $\mathrm{X} 22 \rightarrow \mathrm{X} 2$ & 1.000 & 0.875 & 0.765 & 3.258 & 44.026 & \\
\hline 9 & $\mathrm{X} 23 \rightarrow \mathrm{X} 2$ & 1.000 & 0.873 & 0.763 & 3.213 & 49.333 & \\
\hline 10 & $\mathrm{X} 24 \rightarrow \mathrm{X} 2$ & 1.000 & 0.918 & 0.842 & 5.349 & 62.946 & \multirow{4}{*}{$\begin{array}{l}\mathrm{X} 2 \text { has significance effect on } \mathrm{Y} \text {, as Tstat.(8.251) }> \\
1.98 \rightarrow \text { Ho is rejected }\end{array}$} \\
\hline 11 & $\mathrm{Y} 1 \rightarrow \mathrm{Y}$ & 1.000 & 0.895 & 0.801 & 4.032 & 56.226 & \\
\hline 12 & $\mathrm{Y} 2 \rightarrow \mathrm{Y}$ & 1.000 & 0.902 & 0.814 & 4.379 & 63.418 & \\
\hline 13 & $\mathrm{Y} 3 \rightarrow \mathrm{Y}$ & 1.000 & 0.814 & 0.662 & 1.961 & 29.070 & \\
\hline 14 & $\mathrm{Y} 4 \rightarrow \mathrm{Y}$ & 1.000 & 0.835 & 0.698 & 2.307 & 30.254 & \multirow{2}{*}{$\begin{array}{l}\text { Both } \mathrm{X} 1 \& \mathrm{X} 2 \text { have significance effects on } \mathrm{Y} \text {, as } \\
\mathrm{F}_{\text {statistic }}(230.365)>\mathrm{F}_{\text {table }}(2.441) \rightarrow \text { Ho is rejected }\end{array}$} \\
\hline 15 & $\mathrm{X} 1 \& \mathrm{X} 2 \rightarrow \mathrm{Y}$ & & & 0.792 & & & \\
\hline
\end{tabular}

Note: The formula for finding the $\mathrm{Q}^{2}$ and $\mathrm{F}_{\text {statitic }}$

1) $\mathrm{Q}^{2}=1-\left(1-\mathrm{R}^{2}\right)=1-(1-0.792)=0.792$

2) $\mathrm{F}_{\text {Statistic }}=\left[\left(\mathrm{R}^{2} / \mathrm{k}\right) /\left[1-\mathrm{R}^{2}\right) /() \mathrm{n}-\mathrm{k}-1\right)=[(0.792) / 2] /[(1-0.792) /(124-2-1)=230.365$

\section{Hypothesis Testing Result:}

1) $\mathrm{Ho}(1)$ is rejected $\rightarrow$ The effect of Partnership development capability on building online business performance for woman entrepreneur is significant.

2) $\operatorname{Ho}(2)$ is rejected $\rightarrow$ The effect of Digital marketing capability on building online business performance for woman entrepreneur is significant .

3) $\mathrm{Ho}(3)$ is rejected $\rightarrow$ Simultaneously, both Partnership development and Digital marketing capability have a significant effect on building online business performance for woman entrepreneur.

\section{Discussion}

Findings of verification research have shown that the Partnership development and digital marketing capability had a significant influence on building online business performance for woman entreprenur in Indonesia. The path coeficient of digital marketing capability seems smaller than partnership development capability, which illustrates that partnership development capability has more impact than digital marketing capability does. The simulatenous effects of both Partnership development and Digital marketing capability on Online business performance were $79.2 \%$, while the partialy effects was $29.6 \%\left(=0.54^{2}\right)$ and $21.07 \%\left(=0.459^{2}\right)$, respectivly. Total partial effects were $50.23 \%$, smaller than simultaneous effects (79.2\%). This illustrates that both Partnership development capability and Digital marketing capability are the complementary combinations that simulataneously contributed for the successful online business performance. This emphasizes that if women entrepreneurs need to have the sustainable business performance, they are suggested to build their capability, simultaneously on partnership development and digital marketing. As shown in the Table 3, the effects of partnership development capability $(29.6 \%)$ is greater than digital marketing capability $(21.07 \%)$, which means by the same effort, the impact of partnership development capability is more powerful $(40.5 \%)$ than digital marketing capability. Among of constructs that forming the variable of partnership development capability, wherein the biggest one is Partner selection $(\lambda=0.902)$ and next is Partnership strategy formulation $(\lambda=0.876)$. Thus, it is further necessary for women entrepreneur to focus on increasing their knowledge and skills on how to select the suitable partners and how to develop the effective partnership strategy. The constructs that have the greatest contribution in forming of digital marketing capability are marketing communication $(\lambda=0.918)$ and search engine optimization $(\lambda=0.875)$. Thus, it is further necessary for woman entrepreneur to focus on increasing their knowledge and skill on how to manage marketing communication and search engine optimization. 


\section{Conclusion}

1) Online woman entrepreneurs in Indonesia, generally are the scale of MSMEs which need strategic capability to overcome their limitations, mainly in financial aspects, technology and HR capabilities. Presently, the performance of online woman entrepreneur in Indonesia is still less superior, which is related to their less ability to build strategic capability which can be formed by both strategic partnership development and digital marketing capability, simultaneously

2) Partnership development capability and digital marketing capability were identified as core competencies in building superior online business performance for woman entrepreneur in Indonesia.

3) Both partially and simultaneously, partnership development capability and digital marketing capability have significant effects on building online business performance for Woman Entrepreneur in Indonesia.

4) The impact of partnership development capability on building superior business performance is more powerful than digital marketing capability.

\section{References}

Barney, J. (2001). Is the resource-based "view" a useful perspective for strategic management research? Yes, 26, 41-56.

Batemen, T. S., \& Snell, S. A. (2007). Management Leading \& Collaborating in Competitive World (Vol. 7ed). New York: McGrawHill.

Boose, D. C. (2010). Modern Marketing: Principle and Practice. Phi Learning Private Limited, New Delhi

Bremser, W. G., \& Chung, Q. B. (2005). A framework for performance measurement in the e-business environment. Electronic Commerce Research and Applications, 4(4), 395-412.

Chaffey, D., \& Ellis-Chadwick, F. (2019). Digital marketing. UK: Pearson.

Ghazali, I. (2014). Structural Equation Modeling. Metode Alternatif dengan Partial Least Square (PLS). Semarang: Universitas Dipenogoro.

Hair, J., Hult, G., Ringle, C., \& Sarstedt. (2014). A primer on partial least squares structural equation modeling (PLS -SEM.

Hayes, M. (2015). 32 Key Performance Indicators (KPIs) for Ecommerce.

Indonesia-Investment. (2018, August). Value of E-Commerce Transactions in Indonesia Predicted to Soar. Retrieved from Indonesia-Investments: http://Indonesia-Investments.com

Ireland, D., Hoskisson, R., \& Hitt, M. (2013). The Management of Strategy: Concepts and case. South-Western Cengage Learning.

Isoraite, M. (2009). Importance of Strategic Alliances in Company's Activity. Intellectual economies, 1(5), 39-46.

Maguire, R. (2014). ASEAN eCommerce Is ASEAN at an inflection point for eCommerce?, UBS Q Series.

Opreana, A., \& Vinerean, S. (2015). A new development in online marketing: Introducing digital inbound marketing. Expert Journal of Marketing, 3(1), 29-34.

Prahalad, C. K., \& Hamel, G. (1990). Core competency concept. Harvard Business Review, 64(3), 70-92.

Ryan, D. (2016). Understanding digital marketing: marketing strategies for engaging the digital generation. Kogan Page Publishers.

Sihotang, J. (2016). Effects on Dynamic Capability and Strategic Alliance Formation on Sustainable Competitive. Advantage. IJECM, IV (6), 317-351.

Sri, M., \& Sucherly, H. S. (2012). How Word of Mouth Influence Brand Equity of Automotive Products in Indonesia. Journal of Social and Behavioral Science.

Triantono, H. B., \& Puspokusumo, R. A. (2018). The Role of Ecosystems in the Development of Fintech Dynamics in Indonesia. Binus University.

Wheelen, T.L., Hunger, J. D. (2012). Strategic Management and Business Policy: Toward Global Sustainability. Pearson Prentice Hall.

Zhang, H., \& Okoroafo, S. C. (2014). An e-commerce key success factors framework for Chinese SME exporters. International Journal of Economics and Finance, 6(1), 129-137.

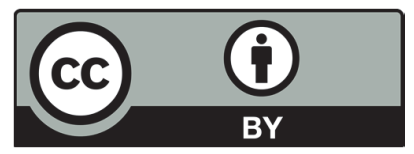

(C) 2020 by the authors; licensee Growing Science, Canada. This is an open access article distributed under the terms and conditions of the Creative Commons Attribution (CC-BY) license (http://creativecommons.org/licenses/by/4.0/). 